\title{
The miniature echinoid trace fossil Bichordites kuzunensis isp. nov. from early Oligocene prodelta sediments of the Mezardere Formation, Gökçeada Island, NW Turkey
}

\author{
HURÍYE DEMÍRCAN ${ }^{1}$ AND ALFRED UCHMAN ${ }^{2}$ \\ ${ }^{1}$ Department of Geological Research, General Directorate of Mineral Research and Exploration (MTA), \\ 06520, Ankara, Turkey. E-mail: asmin68@yahoo.com.tr \\ ${ }^{2}$ Institute of Geological Sciences, Jagiellonian University, Oleandry 2a; PL-30-063 Kraków, Poland. \\ E-mail: alfred.uchman@uj.edu.pl
}

\begin{abstract}
:
Demírcan, H. and Uchman, A. 2012. The miniature echinoid trace fossil Bichordites kuzunensis isp. nov. from early Oligocene prodelta sediments of the Mezardere Formation, Gökçeada Island, northwest Turkey. Acta Geologica Polonica, 62 (2), 205-215. Warszawa.

The pascichnial trace fossil Bichordites kuzunensis isp. nov. occurs as an epichnial complex structure in early Oligocene prodelta sediments of the Thrace Basin in Gökçeada Island, northwest Turkey. It displays characteristics of irregular echinoid burrows such as overall shape and a double meniscate filling with a chevron dorsal suture, in addition to the feature typical of the so far monospecific Bichordites Plaziat and Mahmoudi, 1988, that is a single central core around a single drainage tube. Its miniature size can be related to the small size of the tracemaker (ontogenic feature) or to its dwarfism in a stressed deltaic environment (palaeoecological feature). Its occurrence indicates a period of fully marine conditions during accumulation of the deltaic sediments of the Mezardere Formation.
\end{abstract}

Key words: Bichordites kuzunensis; Ichnology; Ichnotaxonomy; New taxa; Pascichnia; Prodelta; Oligocene; Thrace Basin; Turkey.

\section{INTRODUCTION}

Burrowing irregular echinoids are important components of ecosystems since the Jurassic (e.g. Kier 1982), and spread out from shelf to the deep sea environments since the Tithonian (Tchoumatchenco and Uchman 2001). So far, four ichnogenera are related to them, in particular Scolicia de Quatrefages, 1849, Bichordites Plaziat and Mahmoudi, 1988, Ereipichnus Monaco et al., 2005, and Cardioichnus Smith and Crimes, 1983. The first three are locomotion and feeding traces (pascichnia), and the last one is a resting trace (cubichnion). Bichordites was so far a monospecific ichnogenus, with $B$. monastiriensis Plaziat and Mahmoudi, 1988, being its only ichnospecies. Detailed morphological analysis of a small irregular echinoid trace fossil allowed the establishment of a new ichnospecies of Bichordites. The trace was found in prodelta sediments of the Mezardere Formation (lower Oligocene) in Gökçeada Island, northwest Turkey (Textfig. 1). Its palaeoenvironmental setting is unusual for this ichnogenus, because B. monastiriensis is known mostly from shoreface clastics. The description and interpretation of this burrow is the main aim of this paper. 


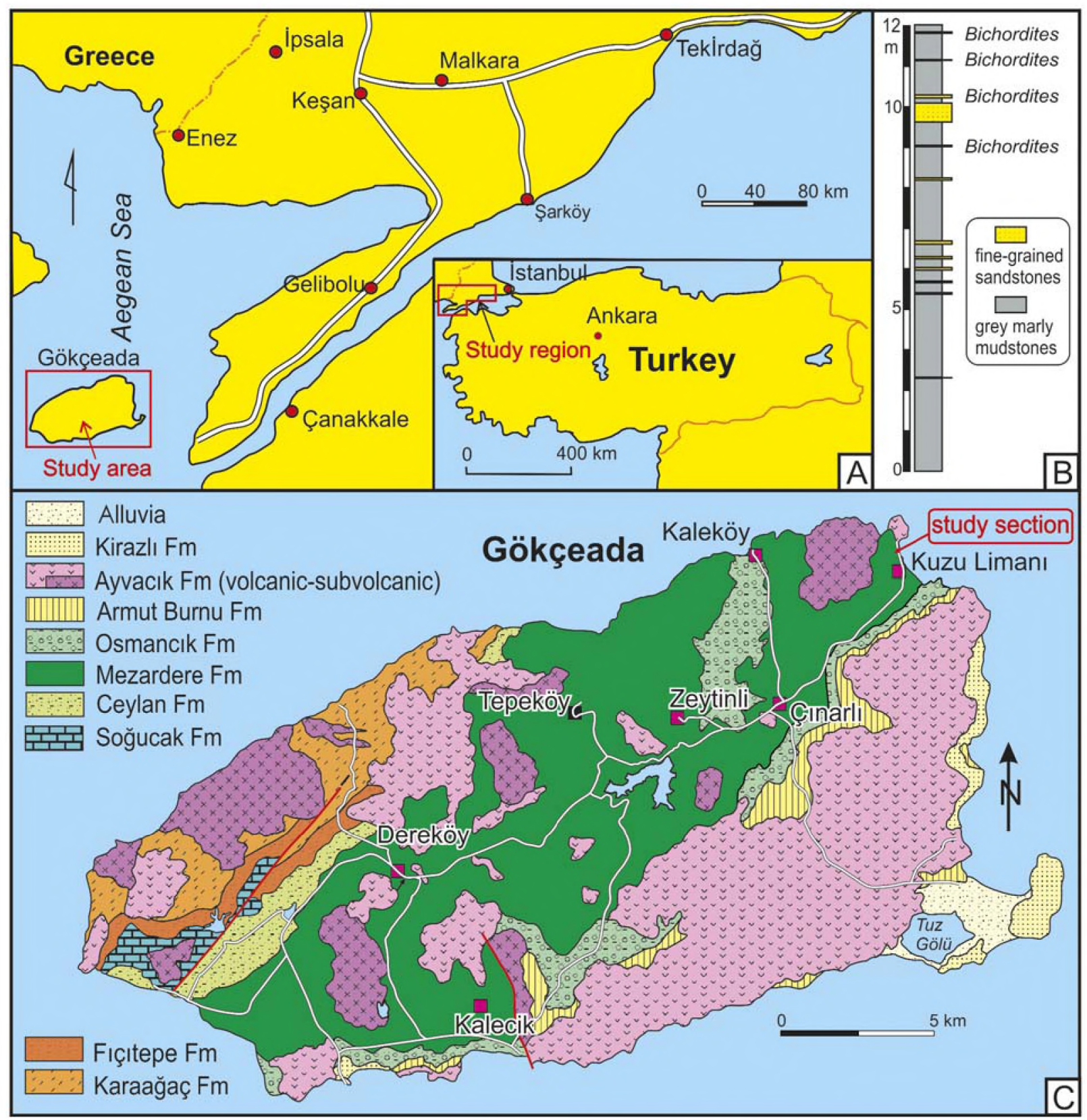

Text-fig. 1. Location maps. A - The study region and its location in Turkey. B - log of the studied section. C - Geological map of Gökçeada Island (based on Temel and Çiftçi 2002). Location of the studied section indicated.

\section{GEOLOGICAL SETTING}

The succession of the Thrace Basin in northwest Turkey is up to $9000 \mathrm{~m}$ thick. In Gökçeada Island (Text-fig. 1A, C), it reaches a thickness of $2000 \mathrm{~m}$, and is composed of Eocene-Miocene deep-sea to shallow-marine and non-marine, mostly clastic sediments, which are intruded and partly covered by Late Oligocene and Late Miocene volcanics (e.g. Turgut et al. 1983; Turgut and Eseller 1999). The
Yenimuhacir Group (upper Eocene to Oligocene), formed by the Mezardere, Osmancık and Danişment formations, is composed mostly of deltaic sediments (Siyako 2006; Siyako and Huvaz 2007). The Mezardere and Osmancık formations are recognised in Gökçeada Island.

The Mezardere Formation (Gökçen 1967; Saner 1985; Sümengen et al. 1987) was named earlier the Mezardere Shale (Ünal 1967) or the Muhacir Formation (Lebküchner 1974). It is 500-2500 m thick and 
composed mostly of mudstones, siltstones and thin- or medium-bedded, poorly sorted sandstones that are important source rocks for gas (Karahanoğlu et al. 1995; Hoşgörmez and Yalçın 2005). The Mezardere Formation overlies sandy flysch deposits of the Keşan Formation (middle-upper Eocene) or shaley-sandy flysch deposits with tuffites of the Ceylan Formation (upper Eocene), and is overlain by delta front sediments with coals, limestones and volcanics of the Osmanck Formation (Siyako 2006).

In Gökçeada Island, the Mezardere Formation (Temel and Çiftçi 2002; Kesgin and Varol 2003; authors' own unpublished observations) is $400-900 \mathrm{~m}$ thick. It is composed mostly of thinly-bedded lightgrey calcareous mudstones and siltstones, which display shale fissility, fine parallel lamination or rarely ripple lamination. Locally, carbonate concretions are present. The fine-grained sediments are intercalated with isolated thin beds of very fine- or fine-grained, slightly muscovitic sandstones, which display parallel lamination in the lower part and ripple lamination in the upper part, or only ripple lamination. Fine carbonized plant detritus is dispersed in the sandstones. The palynomorphs indicate a late Eocene-early Oligocene age (Ediger and Alişan 1989; Batı et al. 1993, 2002). An early Oligocene age is also documented by dinocysts (Temel and Ciftici 2002). In many parts of the island, the Mezardere Formation is intruded by volcanic rocks.

The deposits of the Mezardere Formation are generally interpreted as representing a deltaic environment, from delta front to prodelta (Temel and Çiftçi 2002), or to prodelta only (Siyako and Huvaz 2007). In Gökçeada Island, the Mezardere Formation is dominated by the prodelta facies, with a $50-80 \mathrm{~m}$ water depth estimated by basin modelling (Hoşgörmez and Yalçın 2005). Locally, sandstones of distal or even proximal mouth bars are present.

A 12 m thick succession, dated as early Oligocene, was measured in the upper part of the Mezardere Formation (Text-fig. 1B). It crops out in scarps and small gorges along the road running NW of Kuzulimanı harbour (Text-fig. 2A; GPS co-ordinates: N40¹3.732'; E025 $\left.56.719^{\prime} ; \pm 5 \mathrm{~m}\right)$. Bluish-grey marly mudstones are sporadically intercalated with thin, rarely mediumand thick-bedded sandstones. The presence of sandstone beds suggests an upper prodelta setting influenced by mouth bars.

The studied trace fossil occurs in four beds (Textfig. 1B), which are, from bottom to top, 3.5, 7, 2.5, and $4 \mathrm{~cm}$ thick. The lowest bed is fine-grained, parallel laminated in the lower part and ripple laminated in the upper part. Its lower surface is even, and its upper sur- face (Text-fig. 2B) is uneven and strongly bioturbated. This bed contains rare muscovite flakes and dispersed fine plant detritus. The other beds are similarly composed.

The deltaic sediments of the Mezardere Formation in the Thrace Basin are still poorly studied ichnologically. Only the hunting fish trace Osculichnus labialis Demírcan and Uchman, 2010, and associated Lockeia and Planolites, have been recognized near Malkara in the northwest part of Turkey (Demírcan and Uchman 2010).
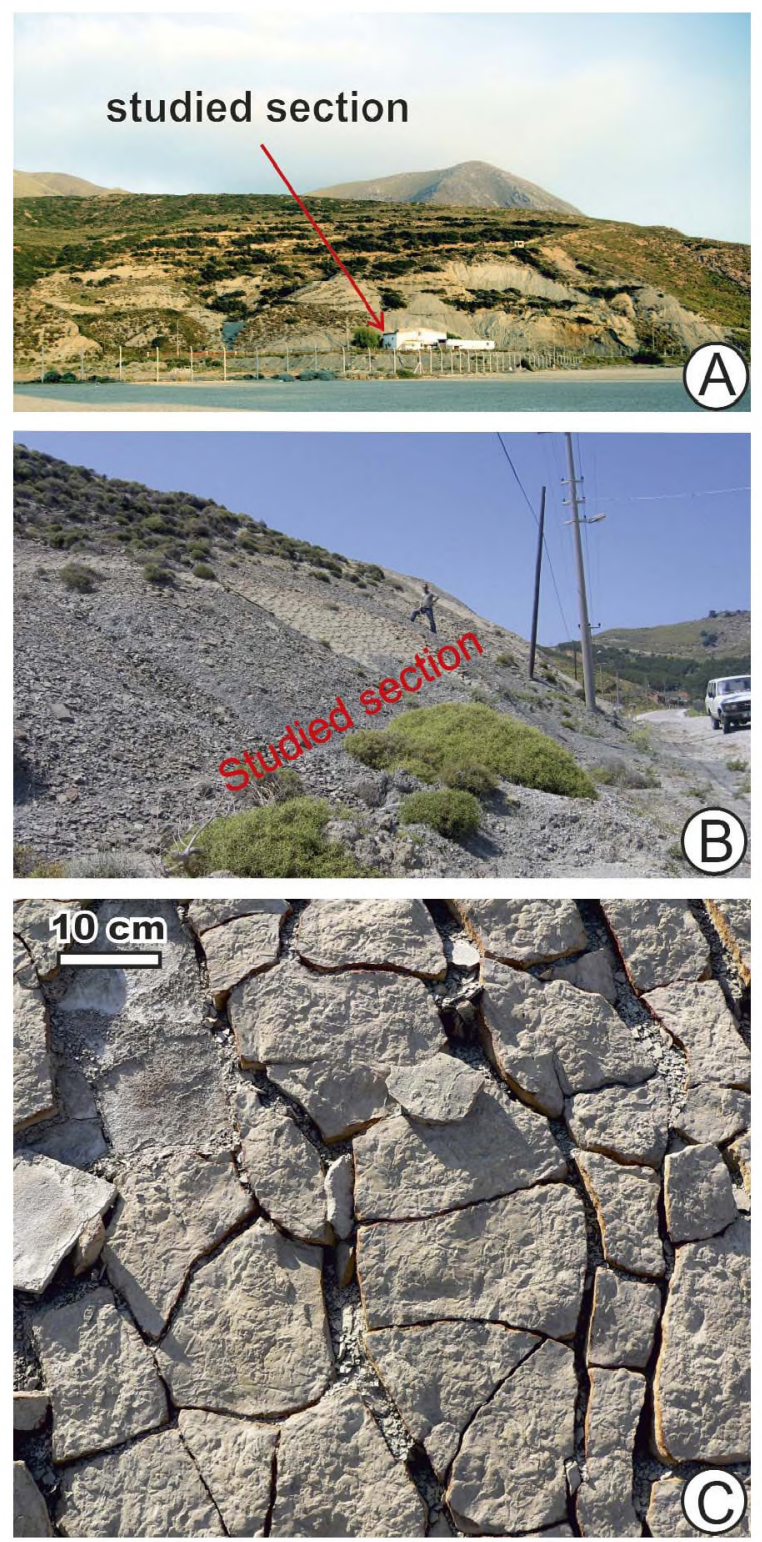

Text-fig. 2. The studied section of the Mezardere Formation. A - view from Kuzulimanı harbour, with position of measured section indicated (Text-fig. 1B). B -view of the section. C-upper, strongly bioturbated surface of the first bed with Bichordites in the measured section (Text-fig. 1B) 
DESCRIPTION OF THE TRACE FOSSIL

\author{
Bichordites Plaziat and Mahmoudi, 1988
}

TYPE ICHNOSPECIES: Bichordites monastiriensis Plaziat and Mahmoudi, 1988.

EMENDED DIAGNOSIS: Predominantly horizontal, cylindrical or subcylindrical, straight to winding, unbranched, meniscate, complex burrow with a central bilobate core.

DISCUSSION: The original diagnosis was slightly modified by Uchman (1995) to: "Predominantly horizontal, cylindrical, straight to winding, unbranched meniscate composite burrow, slightly concave along the base and the top, and with central core. At least the upper part of the burrow contains a double row of menisci. The core is preferentially preserved; it is heart-shaped to ovoid in cross-section, tapers locally and is interrupted. A longitudinal median shallow groove along the top of the core locally passes into an indistinct crest. Locally, the core is covered with external irregular constrictions or transverse striae." This diagnosis applies only to Bichordites monastiriensis. Therefore, the diagnosis of the ichnogenus is emended in order to include the morphological features in common of $B$. monastiriensis and of the new ichnospecies described herein.

A double row of menisci in the upper part of burrows was also described in the ichnogenus Laminites Ghent and Henderson, 1966, and it is a characteristic feature of both Scolicia and Bichordites. The main difference between the two ichnogenera is the presence of structures related to the single drainage tube in $\mathrm{Bi}$ chordites (the central core) and to the double drainage tube in Scolicia (Uchman 1995; Asgaard and Bromley 2007 and references therein).

Bichordites is produced by irregular echinoids with a single drainage tube that belong to the Echinocardium group (Plaziat and Mahmoudi 1988) of the family Echinocardiidae (Asgaard and Bromley 2007), and to spatangoid echinoids of the family Maretiidae (Gibert and Goldring 2007; Bernardi et al. 2010). It is known from the Oligocene (Bernardi et al. 2010) to Pleistocene (e.g. Nara 2004), and its Recent finds are referred to as the "Echinocardium burrows" (e.g. Bromley et al. 1995).

Bichordites kuzunensis isp. nov. (Text-figs 3A-F, 4A-D)
DERIVATION OF NAME: Latinized Turkish kuzun a small goat, which is a common animal on the island, and in reference to Kuzuliman1, which is the main harbour of Gökçeada Island and near the section studied.

MATERIAL: Thirty-two slabs housed in the Museum of Natural History of the General Directorate of Mineral Research and Exploration in Ankara (institutional abbreviation Tr, specimens Tr1K-2008-Tr32K-2008). Four slabs are housed in the Museum of Geology in the Institute of Geological Sciences, Jagiellonian University, Cracow (specimens INGUJ224P1-4).

TYPES: Holotype - Tr4A-K-2008 (Text- fig. 3B); paratype - Tr4B-K-2008 (Text-fig. 3F).

DIAGNOSIS: Subcylindrical Bichordites with basal keel-like shape and mantle.

DISCUSSION: In well preserved specimens, the mantle can show a corrugated surface, the central core can contain an internal tube, and the contact between the two rows of menisci can display a chevron pattern.

DESCRIPTION: A horizontal, winding or rarely almost straight epichnial burrow, the lower part of which is keel-like (obtuse triangle) in cross section (Text-figs 4E, 5). Its upper part is semi-elliptical or almost flat. The burrow is $6-11 \mathrm{~mm}$ wide (mean = $7.9 \mathrm{~mm} ; \mathbf{n}=21$ ). The lower side of the burrow was observed only from the interior. The morphology of the internal part varies depending on the level of the trace sectioned by the bedding surface (Text-figs 3 , 4). In many specimens, a central core is observed in the middle part of the burrow. It is $3-5.5 \mathrm{~mm}$ wide, slightly bilobate or almost flat. The lobes of the central core are separated by a thin, indistinct furrow (Text-figs 3A, D, F, 4B). The surface of the core is covered with transverse ribs (8-12 ribs per $1 \mathrm{~cm}$ ), which locally show a low amplitude chevron pattern along the furrow. Kinks of the chevrons are unidirectional along the central core. Locally, where the central core is deeply eroded, a central, smooth tunnel $(1.1-1.5 \mathrm{~mm}$ in diameter) is present within the core (Text-figs 3A, D, 4D). The burrow fill on both sides of the central core display a meniscate fill (Text-fig. 4B, E). The menisci extend from the transverse ribs of the central core. They run as arcs and join the burrow margins tangentially (Text-fig. 3D). The concavity of the ares is unidirectional, consistent with the direction of the chevron kinks of the central core ribs. The burrow fill above the cen- 
NEW ECHINOID TRACE FOSSIL FROM EARLY OLIGOCENE

tral core contains two rows of menisci, which form continuous arcs, without distinct chevrons. In the upper part of the burrow, the two rows of menisci join along the middle part of the burrow and form a chevron suture (Text-fig. 4D). The suture is about $3 \mathrm{~mm}$ wide and is herein called the dorsal suture. At least the upper surface of more complete burrows shows an external mantle, which is a blanket about $1 \mathrm{~mm}$ thick (Text-fig. 3A-C, E). The surface of the mantle is corrugated. The corrugations are formed mainly by irregular mounds, up to $1 \mathrm{~mm}$ wide.
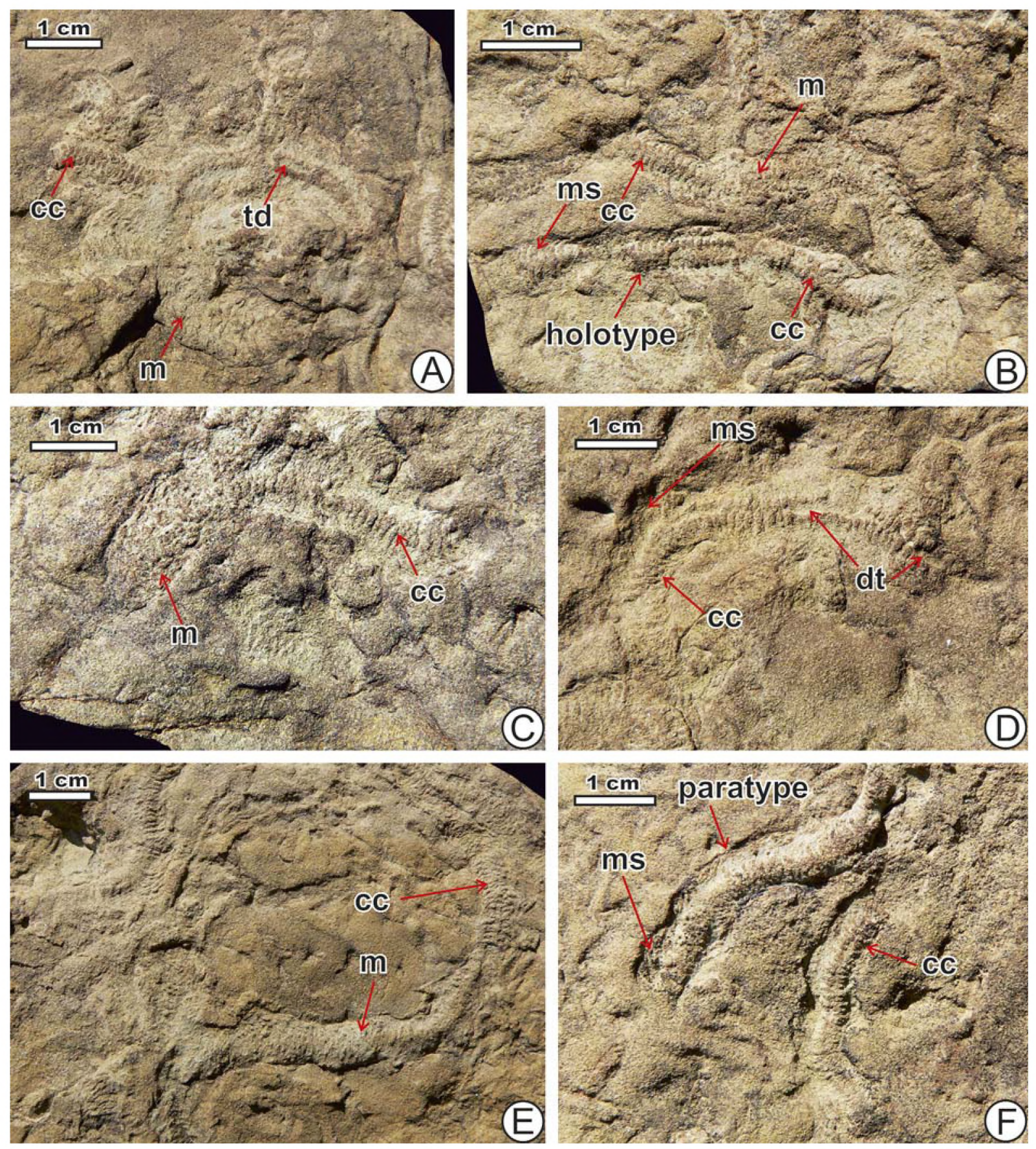

Text-fig. 3. Bichordites kuzunensis isp. nov., its types and morphological variability. All specimens are epichnia in fïne-grained sandstones. Mezardere Formation (lower Oligocene), Gökçeada Island. Morphological elements: cc - central core; $\mathbf{m}$ - mantle; ms - menisci, td - true drainage tube. A - specimen Tr4A-K-2008. B - specimen Tr4A-K-2008 with the holotype. C - specimen Tr4-K-2008. D - specimen Tr4-K-2008. E-specimen Tr4-K-2008. F -specimen Tr4B-K-2008 with the paratype 

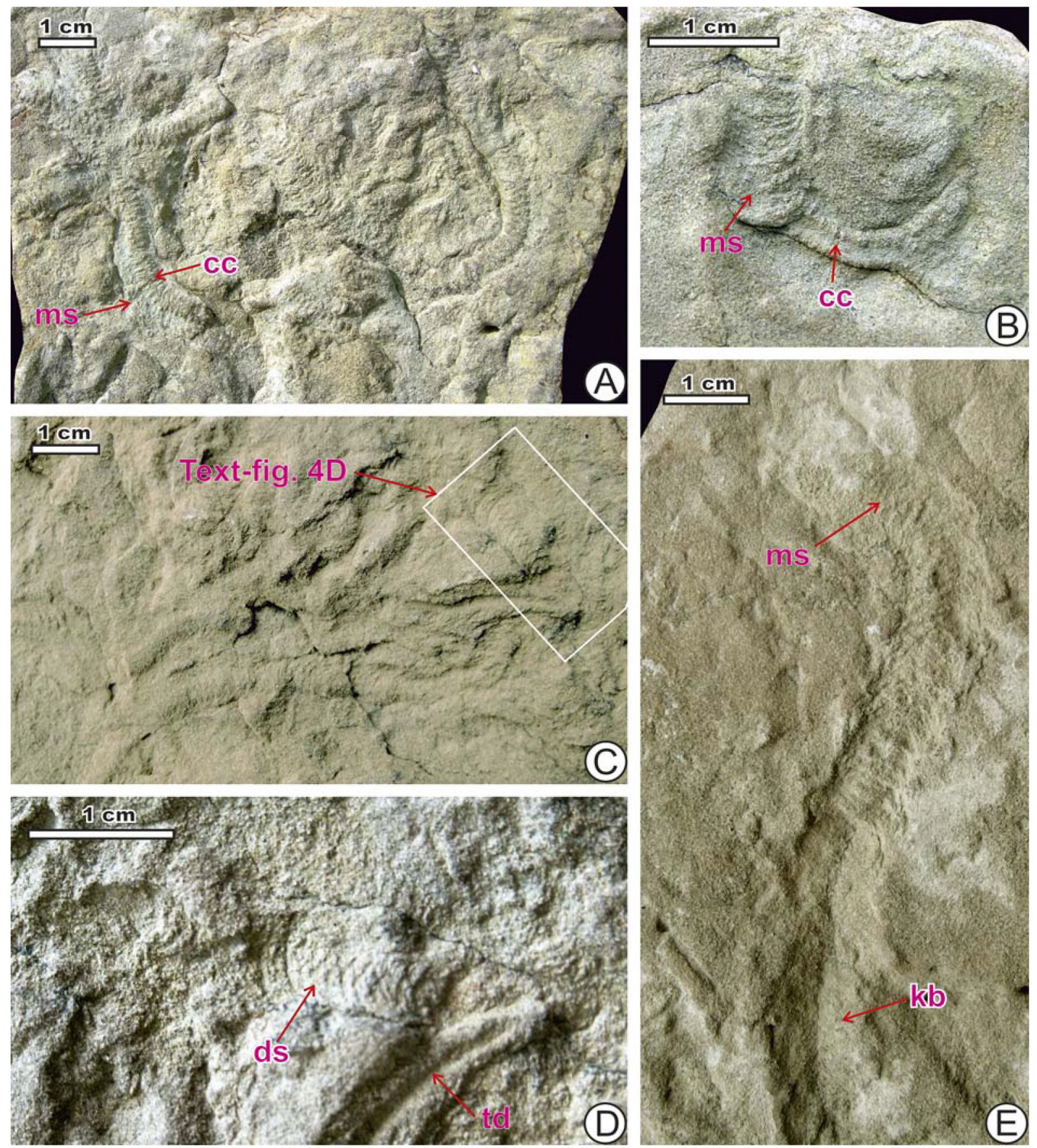

Text-fig. 4. Bichordites kuzunensis isp. nov., other specimens. All specimens are epichnia in fine-grained sandstones. Mezardere Formation (lower Oligocene), Gökçeada Island. Morphological elements: cc-central core; ds - dorsal suture; kb-keel-like base; td - true drainage tube. A-specimen Tr1-K-2008. B - specimen Tr1 A-K-2008. C - specimen Tr1B-K-2008. D - Detail of C. E - specimen Tr1C-K-2008

\section{DISCUSSION}

\section{Interpretation of the burrow}

Detailed analysis of the morphological variants of Bichordites kuzunensis isp. nov., which are here considered as preservational variants, enabled the re- construction of a three-dimensional burrow model (Text-fig. 5). The preservational variants display transitions between each other, these being particularly visible where the burrow changes its depth slightly relative to the bedding surface. The reconstructed burrow is compared with ichnotaxa of similar morphology. 
In its winding course, transverse ribbing and meniscate fill, the trace fossil under discussion is similar to Psammichnites plummeri (Fenton and Fenton, 1937), formerly Olivellites plummeri Fenton and Fen-

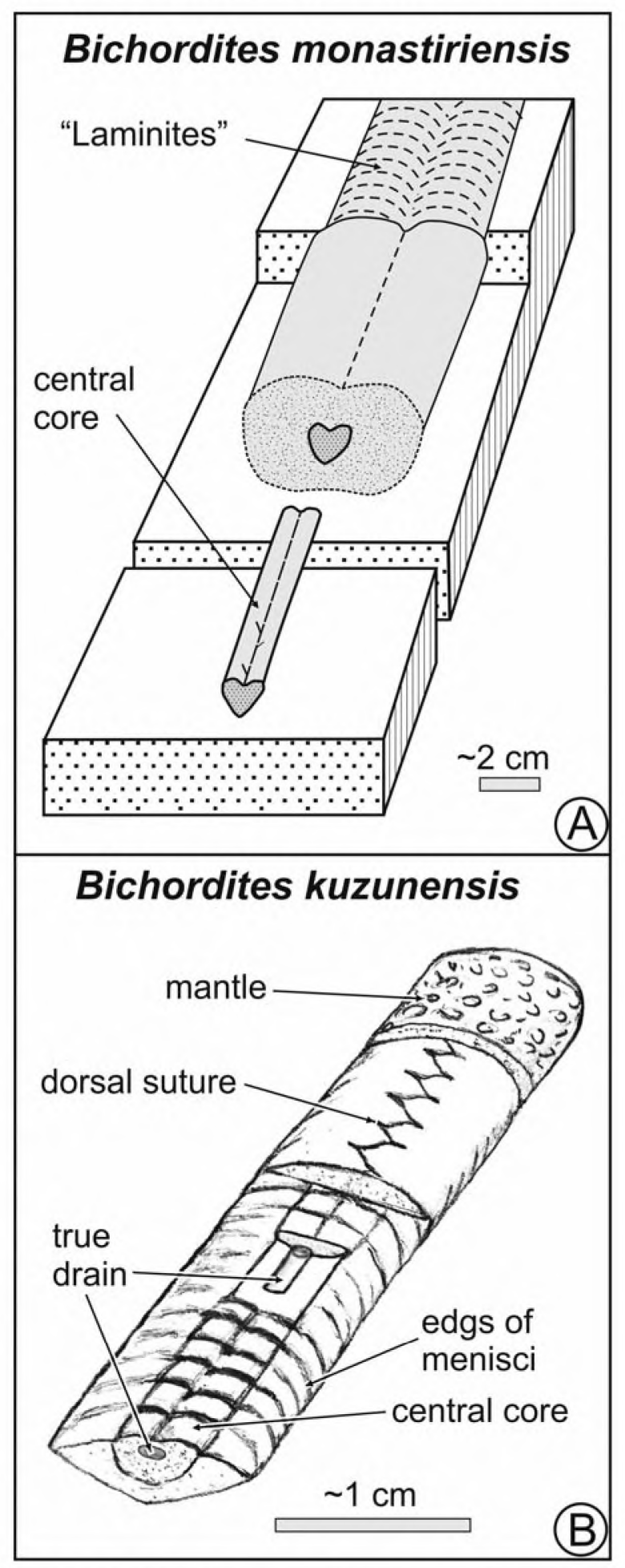

Text-fig. 5. Models of Bichordites. A - Bichordites monastiriensis (adapted from Uchman, 1995). B - Bichordites kuzunensis isp. nov. ton, 1937, which is a Palaeozoic trace fossil common in shallow marine clastic deposits (see Mángano et al. 2002 for review). However, P. plummeri displays a characteristic straight dorsal ridge or groove, which is absent in B. kuzunensis.

The combination of a complex meniscate fill, exhibiting a double row of menisci and the dorsal suture, together are features of irregular echinoid burrows; specifically, the single central core is diagnostic of $\mathrm{Bi}$ chordites (Plaziat and Mahmoudi 1988; Uchman 1995). The keel-like lower part of the burrow, as well as the occurrence of a mantle, differentiates $B$. kuzunensis from $B$. monastiriensis (Text-fig. 5). Moreover, $B$. kuzunensis is much smaller (11 $\mathrm{mm}$ in the widest specimen) than B. monastiriensis, which is commonly 15 to $50 \mathrm{~mm}$ wide. The dorsal suture results from the contact between two rows of menisci at the upper surface of the burrow and should be considered as a diagnostic feature of echinoid burrows. It is present in Scolicia (Textfig. 6) and Bichordites (Uchman 1995), being a part of the "Laminites" preservational aspect of these ichnogenera. Laminites Ghent and Henderson, 1966, which is characterized by double arcs of menisci, is considered to be a preservational variant of either Scolicia or Bichordites (Uchman 1995).

The tube within the central core is interpreted as the true drainage tube of the burrowing echinoid (see Nara 2004). The central core is a better cemented zone along the drainage tube than the surrounding material. The better cementation was induced probably by the high amount of mucus secreted by the echinoids, which resulted in an enhanced chemical gradient that could have favoured microbial activity. Due to the better cementation, it is preferentially preserved and is a conspicuous morphological element on weathered bedding surfaces. The ribs on the central core are edges of menisci adhering to the core. The mantle and its surface corrugations resulted from spine movement while the echinoid burrowed.

The keel-like lower side of the burrow can be related to a keel-like shape of the lower side of the test that is present in some irregular echinoids. For instance, many species of Brissopsis Agassiz (known since the Eocene), Echinocardium Gray (known since the Miocene) or Maretia Gray (known since the Middle Eocene) show this feature (Smith and Kroh 2012). The latter two genera are considered as the producers of Bichordites monastiriensis (see discussion of the ichnogenus). The recent Maretia planulata (Lamarck) shows a very flat test (Smith and Kroh 2012), suggesting that a similar, rather flat-tested echinoid, could have been a producer of Bichordites kuzunensis, taking its small vertical extent into account. 


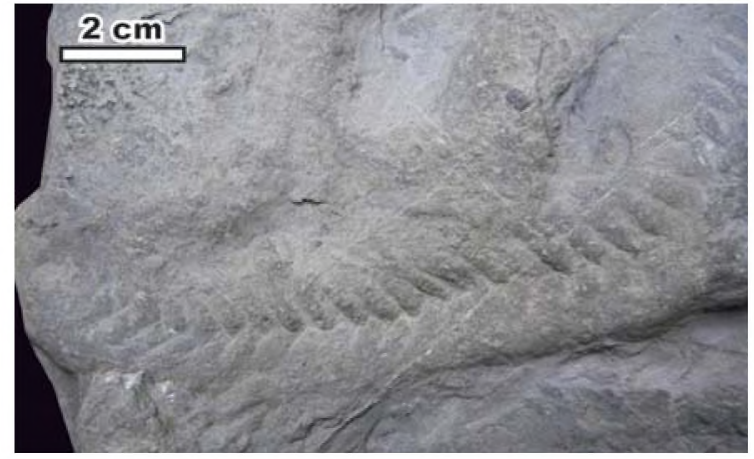

Text-fig. 6. Dorsal suture in Scolicia, epichnion in a turbiditic sandstone-mudstone bed, Beloveža Beds (Eocene), Lipnica Wielka, Poland (specimen TFUJ 1358 from the Książiewiecz collection, originally described as Subphyllochorda, epichnial form, in Książkiewicz 1977, pl. 15, fig. 4; Museum of Geology,

Institute of Geological Sciences, Jagiellonian University, Cracow)

\section{Associated trace fossils and environmental aspects}

The beds with Bichordites kuzunensis also contain Planolites isp., which is an endichnial, epichnial and hypichnial, simple, tubular burrow, $1.2-2 \mathrm{~mm}$ in diameter (Text-fig. 2C). Additional trace fossils occur in other beds in the nearby outcrops. They include tortuous tubes of endichnial Planolites montanus Richter (Text-fig. 7B) and simple, almost straight, lined tubes of Palaeophycus tubularis Hall (Text-fig. 7D), both of which are common. Thin, winding Helminthoidichnites temuis Fitch (Text-fig. 7C) and probably U-shaped vertical burrows visible as pairs of small epichnial depressions (determined as ?Arenicolites isp.; Text-fig. $7 \mathrm{~A})$, are rare.

The diversity of the trace fossil assemblage in the succession is very low. This is a common characteristic feature of deltaic sediments, as this environment is characterized by a high sedimentation rate, inflow of turbid waters and fluctuating salinity, which are the main stress factors limiting trace fossil diversity (e.g. Gingras et al. 1998; Buatois and Mángano 2011). Under such conditions, many tracemakers, especially stenohaline and filter-feeding organisms, do not occur. Echinoid burrows are very rare in deltaic facies. In their review of the ichnology of nine deltaic formations, MacEachern et al. (2005) reported rare Scolicia occurring in one Cretaceous distal delta front sediment. Scolicia is more common in upper shoreface de-
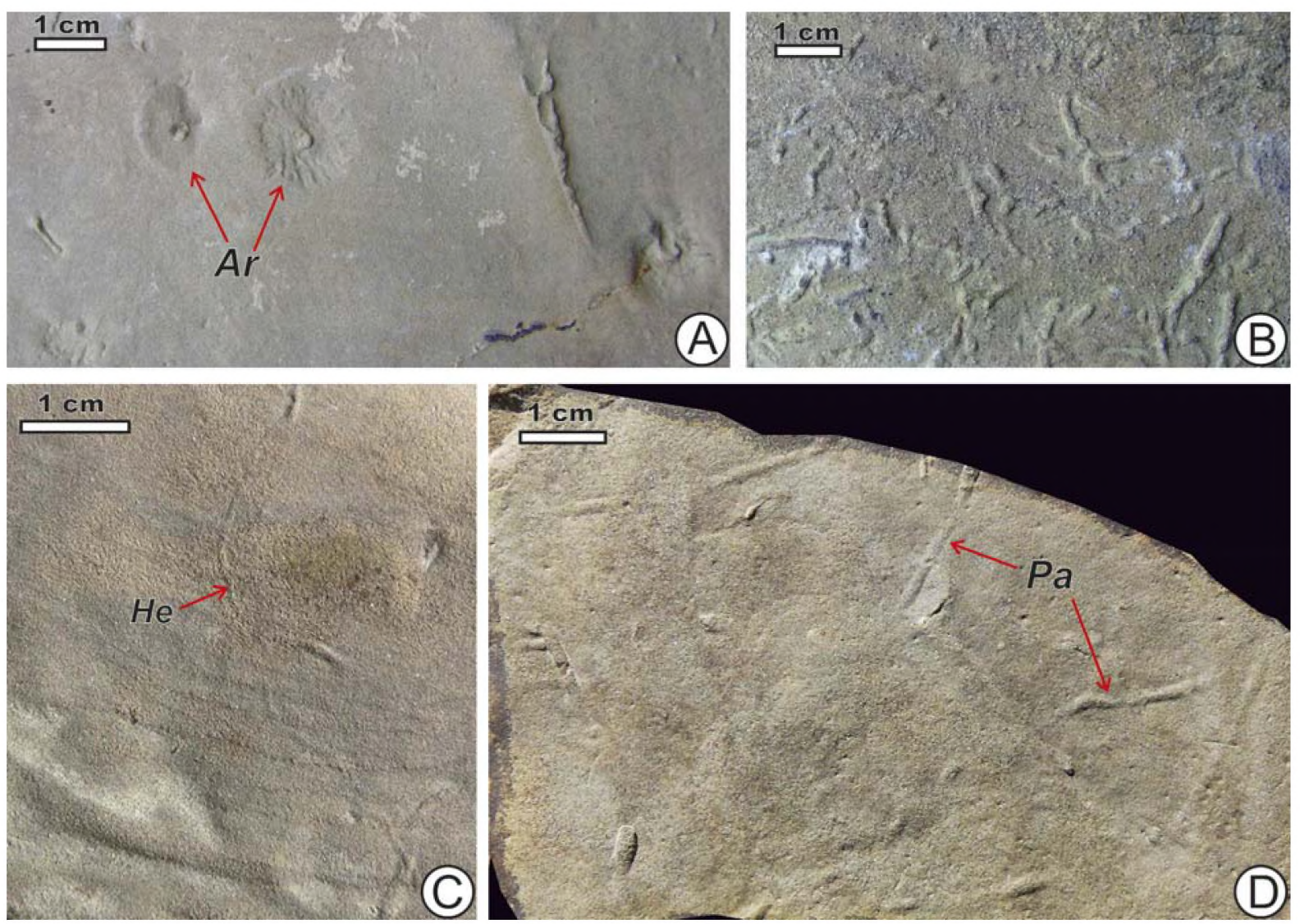

Text-fig. 7. Trace fossils associated with Bichordites kuzunensis in the same exposure; all are hypichnia on fine-grained sandstone bed. Mezardere Formation (lower Oligocene), Gökçeada Island. A - ? Arenicolites isp. (Ar), specimen Tr2-K-2008. B - Planolites montanus, specimen Tr3-K-2008. C-Helminthoidichnites tenuis (He), 
posits of a Miocene wave-dominated delta in Venezuela (Buatois et al. 2008). Chen (2005) reported it from Oligocene deltaic sediments of Taiwan, where it occurs in tempestite sandstone beds; however, judging from the photograph (fig. 10C), this trace fossil may belong to Bichordites because of its distinct single axial element (?central core). Bichordites monastiriensis occurs abundantly in Pleistocene delta front sands of southern Italy (D'Alessandro and Uchman 2007). It was also found in the proximity of an Oligocene coarse-grained delta at Valsugana in northeast Italy (Bernardi et al. 2010). Ayranci and Dashtgard (2011) reported incipient Scolicia and Bichordites from the recent Fraser River delta front in British Columbia, western Canada.

Echinoids as stenohaline organisms (Bromley and Asgaard 1975; Buatois et al. 2005) are especially sensitive to lowered or fluctuating salinity. However, some of them, e.g. Brissopsis lyrifera (Forbes) from the western part of the Danish Straits (Pearson et al. 1985; Josefson and Hansen 2004; Zettler et al. 2000) can tolerate slightly brackish or polyhaline waters (Anonymous 2012). A small-sized echinoid burrow (10-15 mm wide), referred to Scolicia and attributed to Brissopsis lyrifera, was reported from Holocene sediments of the southwest Baltic Sea (Virtasalo 2011), a basin subject to salinity fluctuations during the Holocene and now a brackish sea. Uchman (1995) described Scolicia strozzii (Savi and Meneghini), form A, from the Laga Formation (Apennines), which is only $4-12 \mathrm{~mm}$ wide, the small size probably resulting from environmental stress due to a high sedimentation rate and the late Miocene (Messinian) salinity crisis. Thus, the occurrence of echinoid burrows in environments stressed by lowered or fluctuating salinity is possible, albeit generally rare. Alternatively, the size of burrowing echinoids has been reported to reflect benthic food quality; the higher the nutritious value of the food the larger the animals grow (Kröncke 2006; Wetzel 2008).

Bichordites kuzunensis isp. nov. is distinctly smaller than B. monastiriensis and other echinoid burrows. The small size of the $B$. kuzunensis producer can be either an ontogenetic feature or an effect of dwarfism caused by environmental stress. It is known that dwarfism is common in brackish environments (Kinne 1971), which are expected in the proximity of deltas. Nevertheless, it can be concluded that the occurrence of Bichordites kuzunensis isp. nov. marks an interval of fully-marine or nearly fully-marine conditions during sedimentation of the Mezardere Formation. Irregular echinoids invaded the prodelta sea floor, which was probably at the range of their habitat.

\section{CONCLUSIONS}

A new trace fossil preserved as an epichnial, complex meniscate, winding structure, with a central core, dorsal suture and a mantle, occurs in early Oligocene prodelta sediments of the Thrace Basin in Gökçeada Island, northwest Turkey.

The trace fossil is interpreted as an irregular echinoid burrow and is ascribed to the ichnogenus $B i$ chordites and referred to a new ichnospecies, $B$. kuzunensis.

Its occurrence in the deltaic sediments of the Mezardere Formations indicates a period of normal- or nearly normal-marine but otherwise stressing conditions, as implied by the small burrow size.

\section{Acknowledgements}

The field research was supported by the General Directorate of Mineral Research and Exploration (MTA) in Ankara within the framework of grant 2008-08-16-01-b of the Natural History Museum General Directorate of Mineral Research and Exploration Ankara, Turkey. Additional support was provided by the Jagiellonian University (DS funds). Dirk Knaust (Stavanger), Paolo Monaco (Perugia) and Andreas Wetzel (Basel), the journal referees, offered useful comments, which improved the final version of this paper.

\section{REFERENCES}

Anonymous, 2012. BIOTIC - Biological Traits Information Catalogue [http://www.marlin.ac.uk/biotic/browse.php? $\mathrm{sp}=4376 ; 14.01 .2012]$.

Asgaard, U. and Bromley, R.G. 2007. Co-occurrence of schizastrid echinoids and the trace fossil Scolicia, Pleistocene, Greece: Facts, myths, and fascicoles. In: R.G. Bromley, L.A. Buatois, M.G., Mángano, J.F Genise, and R.N. Melchor (Eds), Sediment-organism interactions: A multifaceted ichnology. Society of Economic Paleontologists and Mineralogists (Society for Sedimentary Geology) Special Publications, 88, 87-95.

Ayranci, H. and Dashtgard, S.E. 2011. Animal-sediment interactions and trace assemblages on the asymmetrical Fraser River delta front and prodelta, British Columbia, Canada. AAPG Annual Conference and Exhibition, Making the Next Giant Leap in Geosciences, April 10-13, 2011, Houston, Texas, USA [http://www.searchanddiscovery.com/abstracts/html/2011/annual/abstracts/Ayranci.html, 12.01.2012].

Batı, Z, Erk, S. and Akça, N. 1993. Trakya Havzası Tersiyer birimlerinin palinomorf, foraminifer ve nannoplankton 
biyostratigrafisi. TPAO Araştırma Dairesi Arşivi, teknik rapor, 1947, 92 s. Turkish Petroleum Corporation, Ankara. [Unpublished report]

Batı, Z, Alişan, C., Ediger, V.Ş., Teymur, S., Akça, N., Sancay, H., Ertuğ, K., Kirici, S., Erenler, M., and Aköz, Ö. 2002. Kuzey Trakya Havzası' nın Palinomorf, Foraminifer ve Nannoplankton Biyostratigrafisi, Türkiye Stratigrafi Komitesi Çalıştayı (Trakya Bölgesi'nin Litostratigrafi Adlamaları) Özleri. In: Türkiye Stratigrafi Komitesi 2. Çalıştayı Trakya Bölgesinin Litostratigrafi Adlamalar1 30/31-Mayıs-2002. MTA Genel Müdürlüğü, Ankara. Bildiri Özleri Kitabı, Ankara, p. 14.

Bernardi, M., Boschele, S., Ferretti, P. and Avanzini, M. 2010. Echinoid burrow Bichordites monastiriensis from the Oligocene of NE Italy. Acta Palaeontologica Polonica, 55, 479-486.

Bromley, R.G. and Asgaard, U. 1975. Sediment structures produced by a spatangoid echinoid: a problem of preservation. Bulletin of the Geological Society of Denmark, 24, 261-281.

Bromley, R.G., Jensen, M. and Asgaard, U. 1995, Spatangoid echinoids: deep-tier trace fossils and chemosymbiosis: Neues Jahrbuch für Geologie und Paläontologie, $A b-$ handlungen, 195, 25-35.

Buatois, L.A., Gingras, M.K., MacEachern, J., Mángano, M.G., Zonneveld, J.-P., Pemberton, S.G., Netto, R.G. and Martin, A. 2005. Colonization of brackish-water systems through time: evidence from the trace-fossil record. Palaios, 20, 321-347.

Buatois, L.A. and Mángano, M.G. 2011. Ichnology: Organisms-Substrate Interactions in Space and Time, pp. 1358. Cambridge University Press; Cambridge.

Buatois, L.A., Santiago, N., Parra, K. and Steel, R. 2008. Animal-substrate interactions in an Early Miocene wavedominated tropical delta: delineating environmental stress and depositional dynamics (Tácata Field, eastern Venezuela). Journal of Sedimentary Research, 78, 458-479.

Chen, W.S. 2005. Characteristic trace fossils from shoreface to offshore environments of an Oligocene succession, northeastern Taiwan. Tao, 16, 1097-1120.

D'Alessandro, A. and Uchman, A. 2007. Bichordites and Bichordites-Rosselia ichnoassemblages from the Lower Pleistocene Tursi Sandstone (southern Italy). In: R.G. Bromley, L.A. Buatois, M.G., Mángano, J.F Genise, and R.N. Melchor (Eds), Sediment-organism interactions: A multifaceted ichnology. Society of Economic Paleontologists and Mineralogists (Society for Sedimentary Geology) Special Publications, 88, 213-221.

Demírcan, H. and Uchman, A. 2010. Kiss of death of a hunting fish: trace fossil Osculichnus labialis igen. et isp. nov. from late Eocene - early Oligocene prodelta sediments of the Mezardere Formation, Thrace Basin, NW Turkey. Acta Geologica Polonica, 60, 29-38.
Ediger, V.Ş. and Alişan, C. 1989. Tertiary fungal and algal palynomorph biostratigraphy of the northern Thrace basin, Turkey. Review of Palaeobotany and Palynology, 58, 139-161.

Fenton, C.L. and Fenton, M.A. 1937. Olivellites, a Pennsylvanian snail burrow. American Midland Naturalist, 18, $452-453$

Ghent, H.D. and Henderson, R.A. 1966. Petrology, sedimentation, and paleontology of Middle Miocene graded sandstones and mudstone, Kaiti Beach, Gisborne. Transaction of the Royal Society of New Zealand, Geology, 4 , 147-169.

Gibert, J.M., de and Goldring, R. 2008. Spatangoid-produced ichnofabrics (Bateig Limestone, Miocene, Spain) and the preservation of spatangoid trace fossils. Palaeogeography, Palaeoclimatology, Palaeoecology, 270, 299-310.

Gingras, M.K., MacEachern, J.A. and Pemberton, S.G. 1998. A comparative analysis of the ichnology of wave- and river-dominated allomembers of the Upper Cretaceous Dunvegan Formation. Bulletin of Canadian Petroleum Geology, 46, 51-73.

Gökçen, L.S. 1967. Keşan bölgesinde Eosen-Oligosen sedimantasyonu, Güneybatı Türkiye Trakyası. Maden Tetkik Arama Dergisi, 69, 1-10.

Hoşgörmez, H. and Yalçın, M.N. 2005. Gas-source rock correlation in Thrace basin, Turkey. Marine and Petroleum Geology, 22, 901-916.

Josefson, A.B. and Hansen, J.L.S., 2004. Species richness of benthic macrofauna in Danish estuaries and coastal areas. Global Ecology and Biogeography, 13, 273-288.

Karahanoğlu, N., Eder, A. and Illeez, A. I. 1995. Mathematical approach to hydrocarbon generation history and source rock potential in the Thrace Basin, Turkey. $\mathrm{Ma}$ rine and Petroleum Geology, 12, 587-596.

Kesgin, Y. and Varol, B. 2003. Gökçeada ve Bozcaada' nın Tersiyer jeolojisi. Maden Tetkik ve Arama Dergisi, 126, 49-67.

Kier, P.M. 1982. Rapid evolution of echinoides. Palaeontology, 25, 1-9.

Kinne, O. 1971. Salinity: 3. Animals: 1. Invertebrates. In: O. Kinne (Ed.), Marine Ecology: A Comprehensive, Integrated Treatise on Life in Oceans And Coastal Waters: 1. Environmental Factors: pp. 821-995. Wiley-Interscience; London.

Kröncke, I. 2006. Structure and function of macrofaunal communities influenced by hydrodynamically controlled food availability in the Wadden Sea, the open North Sea, and the deep-sea. A synopsis. Senckenbergiana maritima, 36, 123-164.

Książkiewicz, M. 1977. Trace fossils in the Flysch of the Polish Carpathians. Palaeontologia Polonica, 36, 1208. 
Lebküchner, R.F. 1974. Orta Trakya Oligosen' inin jeolojisi hakkında. Maden Tetkik Arama Dergisi, 83, 1-29.

MacEachern, J.A., Bann, K.L., Bhattacharya, J.P. and Howell, C.D., Jr. 2005. Ichnology of deltas: organism responses to the dynamic interplay of rivers, waves, storms and tides. In: L. Giosan, and J.P. Bhattacharya (Eds), River deltas concepts, models, and examples. Society of Economic Paleontologists and Mineralogists (Society for Sedimentary Geology) Special Publications, 83, 49-85.

Mángano, G.M., Buatois, L.A. and Rindsberg, A.K. 2002. Carboniferous Psammichnites: A systematic re-evaluation, taphonomy and autecology. Ichnos, 9, 1-22.

Monaco, P., Gianetti, A., Caracuel, J.E. and Yébenis, A. 2005. Lower Cretaceous (Albian) shell-armoured and associated echinoid trace fossils from the Sácaras Formation, Sierra Gelada area, southeast Spain. Lethaia, 38, 333-344.

Nara, M. 2004, Trace fossil Bichordites monastiriensis in Pleistocene shallow marine deposits of the Boso Peninsula, central Japan, and its palaeoenvironmental significance. Journal of the Geological Society of Japan, 110, 545-551. [In Japanese with English abstract]

Pearson, T.H., Josefson, A.B. and Rosenberg, R. 1985. Petersen's benthic stations revisited. I. Is the Kattegatt becoming eutrophic? Journal of Experimental Marine Biology and Ecology, 92, 157-206.

Plaziat, J.-C. and Mahmoudi, M. 1988. Trace fossils attributed to burrowing echinoids: a revision including new ichnogenus and ichnospecies. Geobios, 21, 209-233.

Quatrefages, de, M.A. 1849. Note sur la Scolicia prisca (A. de Q.) annélide fossile de la Craie. Annales des Sciences Naturalles, 3 série, Zoologie, 12, 265-266.

Saner, S. 1985. Saros körfezi ve dolayının çökelme istifleri ve tektonik yerleşimi, Kuzeydoğu Ege denizi, Türkiye. Türkiye Jeoloji Kurumu Bülteni, 28, 1-10.

Siyako, M. 2006. Thrace Basin Tertiary rock units. In: M. Üzer (Ed.), Trakya Bölgesi Litostratigrafi Birimleri [Lithostratigraphic Units of the Thrace Region], pp. 4383. Maden Tetkik ve Arama Genel Müdürlüğü, Ankara. [In Turkish]

Siyako, M. and Huvaz, O. 2007. Eocene stratigraphic evolution of the Thrace Basin, Turkey. Sedimentary Geo$\log y$, 198, 75-91.

Smith, A. B. and Crimes, T. P. 1983. Trace fossils formed by heart urchins - a study of Scolicia and related traces. Lethaia, 16, 79-92.

Smith, A.B. and Kroh A. 2012. The Echinoid Directory. The Natural History Museum [http://www.nhm.ac.uk/re- search-curation/research/projects/echinoid-directory/index.html; 14.01.2012]

Sümengen, M., Terlemez, İ., Şentürk, K., Karaköse, C., Erkan, N.E., Ünay, E., Gürbüz, M. and Atalay, Z. 1987. Gelibolu Yarımadası ve Güneybatı Trakya Tersiyer havzasının stratigrafisi, sedimantolojisi ve tektoniği: MTA genel Müdürlüğü. Jeoloji Etüdler Dairesi, yayımlanmamış teknik rapor, 2121, 1-337. [Unpublished]

Tchoumatchenco, P. and Uchman, A. 2001. The oldest deepsea Ophiomorpha and Scolicia and associated trace fossils from the Upper Jurassic - Lower Cretaceous deepwater turbidite deposits of SW Bulgaria. Palaeogeography, Palaeoclimatology, Palaeoecology, 169, 8599.

Temel, R.Ö. and Çiftçi, N.B. 2002. Stratigraphy and depositional environments of the Tertiary sedimentary units in Gelibolu peninsula and islands of Gökçeada and Bozcaada (Northern Aegean region, Turkey). TAPGTurkish Association of Petroleum Geologists Bulletin, 14, 17-40.

Turgut, S. and Eseller, G. 1999. Sequence stratigraphy, tectonics and depositional history in eastern Thrace Basin, NW Turkey. Marine and Petroleum Geology, 17, 61100 .

Turgut, S., Siyako, M. and Dilki, A. 1983. Geology and hydrocarbon potential of the Thrace Basin. Turkish Geological Congress Bulletin, 4, 35-46.

Uchman, A. 1995. Taxonomy and palaeoecology of flysch trace fossils: The Marnoso-arenacea Formation and associated facies (Miocene, Northern Apennines, Italy). Beringeria, 15, 3-115.

Ünal, O.T. 1967. Geology of Thrace and oil potential. TPO Arama Grubu Arşvi (yayımlanmamış) rapor, 391, 1-80. TPO, Ankara. [In Turkish, unpublished report of the Turkish Petroleum Company]

Virtasalo, J.J., Bonsdorff, E., Moros, M., Kabel, K., Kotilainen, A.T., Ryabchuk, D., Kallonen, A. and Hämäläinen, K. 2011. Ichnological trends along an open-water transect across a large marginal-marine epicontinental basin, the modern Baltic Sea. Sedimentary Geology, 241, 40-51.

Wetzel, A. 2008. Recent bioturbation in the deep South China Sea: A uniformitarian ichnologic approach. Palaios, 23, 601-615.

Zettler, M.L., Bönsch, R. and Gosselck, F. 2000. Verbreitung des Makrozoobenthos in der Mecklenburger Bucht (südliche Ostsee) - rezent und im historischem Vergleich. Meereswissenschaftliche Berichte, 42, 1-144. 